\title{
Clinical and Laboratory Evaluation of Patients Diagnosed with COVID-19 Receiving Favipiravir-based Treatment
}

\section{Favipiravir Temelli Tedavi Alan COVID-19 Tanılı Hastaların Klinik ve Laboratuvar Değerlendirmesi}

(1) Burak SARIKAYA, id Semiha ÇELIK EKINCI

Sultan 2. Abdülhamid Han Training and Research Hospital, Clinic of Infectious Diseases and Clinical Microbiology, İstanbul, Turkey

\begin{abstract}
Objective: Severe acute respiratory syndrome coronavirus-2 (SARS COV-2); can lead to severe respiratory failure. In this study, factors affecting mortality in Coronavirus disease (COVID-19) patients who were hospitalized with hydroxychloroquine (HCQ), azithromycin and favipiravir treatments were investigated.
\end{abstract}

Methods: Between March 10 and May 10, 2020, COVID-19 reverse transcription polymerase chain reaction (RT-PCR) positive treatment naive 683 patients were screened retrospectively. Five hundred four patients were followed without treatment or with HCQ treatment. Out of 179 patients, 137 were hospitalized and 42 were directly admitted to the intensive care unit (ICU). Oxygen saturation of these patients is $<90 \%$, follow-up ( $>30 / \mathrm{min}$ ) and HCQ, azithromycin, favipiravir were started. 35 of 137 patients were transferred to ICU. Mechanical ventilation was provided to $69(89 \%)$ of 77 patients in the ICU. 19 (24\%) patients received tosilizumab and $13(17 \%)$ patients received immune plasma. It was divided into two as healing and exitus. Demographic features, comorbid diseases, secondary bacterial infections and acute organ damage were recorded.

Results: Two hundred of the patients were male and their average age was $60.9 \pm 16.4$ years. HT and diabetes mellitus (DM) were the most common comorbid disease. Acute liver injury was most common. 54 patients became exitus. Exitus group has higher mean age, chronic heart disease (CHD), DM, CRF, acute cardiac damage and secondary bacterial infection are more statistically significant $(\mathrm{p}<0.05)$. Exitus status DM 2.17, COPD 2.18, asthma 3.01,

\section{ÖZ}

Amaç: Şiddetli akut solunum yetmezliği sendromu-2 (SARSCoV-2); hafif enfeksiyonlardan ağır solunum yetmezliğine kadar çeşitli tablolara yol açabilir. Bu çalışmada hastaneye yatırılarak hidroksiklorokin (HCQ), azitromisin ve favipiravir üçlü kombine ilaç tedavileri verilmiş COVİD-19 hastalarında mortaliteye etki eden faktörler incelenmiştir.

Yöntemler: 10 Mart-10 Mayıs 2020 tarihlerinde COVID-19 ters transkripsiyon polimeraz zincir reaksiyonu pozitif tedavi naif 683 hasta retrospektif tarand. 504 hasta hafif semptomu olup ilaç tedavisi verilmeksizin veya tek başına HCQ tedavisi ile takip edilmiş ve şifa ile sonuçlanmıştı. 179 hastadan 137'si kliniğe, 42'si direk yoğun bakım üntesine (YBÜ) yatırılmıştı. Bu hastaların hepsinin oda havasinda oksijen saturasyonu $<\% 90$, takipnesi $(>30 / \mathrm{dk})$ olup eş zamanlı olarak üçlü kombine ilaç tedavisi (HCQ, azitromisin, favipiravir) başlanmıştı. Klinik takipte 137 hastadan 35'i YBÜ’ye nakledilmişti. YBÜ'deki 77 hastanın 69'una (\%89) mekanik ventilatör desteği verilmişti. On dokuz (\%24) hastaya tosilizumab, 13 (\%17) hastaya ise konvelesan immün plazma uygulanmıştı. Hastalar şifa ile taburcu ve eksitus şeklinde ikiye ayrıldı. Demografik özellikler, komorbid hastalıklar, sekonder bakteriyel enfeksiyonlar ve akut organ hasarları kayıt edildi.

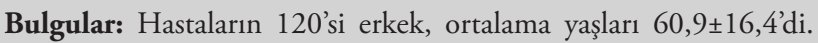
HT ve DM en sık komorbid hastalıktı. En sık akut karaciğer hasarı görüldü. Elli dört hasta eksitus oldu. Eksitus grubunda yaş ortalamasının daha yüksek olması, kronik kalp hastalığı (KKH), DM, kronik böbrek yetmezliği (KBY), akut kardiyak hasar ve
Address for Correspondence: Burak SARIKAYA, Sultan 2. Abdülhamid Han Training and Research Hospital, Clinic of Infectious Diseases and Clinical Microbiology, İstanbul, Turkey E-mail: burak_tibbiyeli@hotmail.com ORCID ID: orcid.org/0000-00002-0026-1927
Received: 22.06 .2020

Accepted: 20.08.2020

Cite this article as: Sarıkaya B, Çelik Ekinci S, Clinical and Laboratory Evaluation of Patients Diagnosed with COVID-19 Receiving Favipiravir-based Treatment. Bezmialem Science 2020;8(Supplement 3):67-73. 
CHD 2.4, CRF 8.3, malignancy 1.6, acute cardiac damage 12.9, secondary bacterial infection development 3.63 times mortality increase statistically significant $(\mathrm{p}<0.05)$.

Conclusion: In patients receiving treatment based on Favipiravir; advanced age, DM, CHD, CKD, troponin-I elevation and secondary bacterial infections are associated with mortality. CRF and troponin-I elevation are predictors of mortality.

Keywords: COVID-19, favipirovir, mortality sekonder bakteriyel enfeksiyon daha fazla görülmesi istatistiksel anlamlı bulunmuştur $(\mathrm{p}<0,05)$. Eksitus durumuna DM 2,17, $\mathrm{KOAH} \mathrm{2,18,} \mathrm{astım} \mathrm{3,01,} \mathrm{KKH} \mathrm{2,4,} \mathrm{KBY} \mathrm{8,3,} \mathrm{malignite} \mathrm{1,6,} \mathrm{akut}$ kardiyak hasar 12,9, sekonder bakteriyel enfeksiyon gelişimi 3,63 kat mortalite artışına neden olup istatistiksel anlamlı $(\mathrm{p}<0,05)$ saptanmıştır.

Sonuç: Favipiravir temelli tedavi alan COVİD-19 hastalarında; ileri yaş, DM, KKH, KBY, troponin-1 yüksekliği ve sekonder bakteriyel enfeksiyonlar mortalite ile ilişkili faktörlerdir. KBY ve troponin-1 yüksekliği bu hastaların mortalitesi için prediktördür.

Anahtar Sözcükler: COVİD-19, favipirovir, mortalite

\section{Introduction}

Coronaviruses $(\mathrm{CoV})$ are RNA viruses that can cause generally mild infections in humans and mammals (1). Severe acute respiratory syndrome coronavirus-1 (SARS-CoV-1) and Middle East respiratory syndrome coronavirus in this group lead to more severe clinical pictures (2). The World Health Organization (WHO) named the new $\mathrm{CoV}$ that emerged in Wuhan, China, as (SARS-CoV)-2, and the disease caused by this virus was named COVID-19 (3). SARS-CoV-2, which is a member of the coronavirus family, may cause mild clinical symptoms or lead to severe respiratory failure and may be mortal.

According to the American Center for Disease Control and Prevention and WHO data, approximately 11.6 million people in the world were diagnosed with COVID-19 and more than 539,900 of them died (4).

Protein synthesis inhibitors, RNA polymerase enzyme inhibitors, viral entry inhibitors, human monoclonal antibody inhibitors, anti-inflammatory and immunomodulatory drugs are used in the treatment of COVID-19. Currently, remdesivir and favipiravir, which are anti-viral agents in phase-3 stage, are used in the treatment of the disease $(5,6)$.

In this study, patients who were hospitalized in a tertiary hospital and received the combined hydroxychloroquine (HCQ), azithromycin and favipiravir therapy were evaluated. It was aimed to determine the factors affecting mortality and comorbid diseases in these patients.

\section{Method}

This study was approved by the University Health of Science, Hamidiye Scientific Research Ethics Committee (decision number 20/182 dated 15.05.2020).

\section{Study Population}

In this study, 683 patients who applied to Ministry of Health Sultan 2. Abdülhamid Han Training and Research Hospital between March 10, 2020 and May 10, 2020 and who were found to be COVID-19 real time-polymerase chain reaction (RT-PCR) positive in nasopharyngeal/oropharyngeal swab samples were retrospectively screened. None of the 683 patients had previously received treatment for COVID-19. 504 of these patients were patients with mild clinical symptoms or asymptomatic, and were followed up on an outpatient basis with hydroxychloroquine treatment for 5 days or without any treatment in line with the COVID-19 guideline recommendation of the Ministry of Health. No mortality was observed in any of the 504 patients; respiratory deterioration requiring initiation of favipiravir therapy did not develop; and resulted in recovery. Out of 683, 179 patients were hospitalized and followed up. Of the 179 patients hospitalized, 137 were admitted to the COVID-19 clinic, the remaining 42 patients were directly admitted to the ICU at the time of admission to the emergency department, after determining the need for ICU. In 137 patients hospitalized in the clinic, dual drug therapy was started as HCQ 2x400 mg and azithromycin 1×500 mg on the first day, HCQ 2x200 mg and azithromycin $1 \times 250 \mathrm{mg}$ for the next 4 days in line with the COVID-19 guideline recommendation of the Ministry of Health. During the follow-up, 2x600 mg maintenance therapy for 4 days was added to patients whose oxygen saturation at room air was $<90 \%$ and tachypnea started $(>30 / \mathrm{min})$ after a loading dose of $2 \times 1600 \mathrm{mg}$ favipiravir on the first day. In 102 of these patients, oxygen saturation in room air increased above $95 \%$ after triple combined drug therapy, their tachypneas improved, did not need intensive care, no mortality occurred and were discharged with full recovery. In 35 patients, despite the initiation of triple combined drug and nasal oxygen treatments, their oxygen saturation remained below $90 \%$, and they were transferred to the ICU due to the need for respiratory support. Fourty two patients were directly admitted to the ICU during their admission to the emergency department despite the oxygen support because their saturation was below $90 \%$, respiration rate $>30 / \mathrm{min}$ or they were found to be hypotensive. In line with the recommendation of the Ministry of Health COVID-19 guideline for patients directly admitted to the ICU, simultaneous triple combined drug therapy (after loading doses of HCQ 2x400 mg, azithromycin $1 \times 500 \mathrm{mg}$, favipiravir $2 \times 1600 \mathrm{mg}$ on the first day, HCQ 2x200 mg, azithromycin 1×250 mg, favipiravir 2x600 $\mathrm{mg}$ for 4 days) was started. 69 of 77 (89\%) patients followed in the ICU were given invasive mechanical ventilator support. In addition to triple combined drug therapies, 19 of 77 (24\%) patients followed in the ICU were administered tocilizumab and $13(17 \%)$ had convalescent immune plasma therapies. 
179 patients who used favipiravir-based triple combination drug therapy included in the study; They were divided into two groups as patients who were discharged after recovery and those who died. Demographic information of the patients such as age and gender, and comorbid diseases such as type 2 diabetes mellitus (DM), essential hypertension (HT), chronic obstructive pulmonary disease (COPD), asthma, coronary heart disease (CHD), malignancy and chronic renal failure (CRF) were recorded. Secondary bacterial infections (blood culture positivity) developed during the follow-up after hospitalization were also recorded to examine the effect on mortality.

At the first admission to the hospital, alanine amino transferase (ALT), aspartate amino transferase (AST), serum urea, serum creatinine, serum troponin-I and estimated glomerular filtration rate (eGFR) were analyzed. A decrease of $<20 \%$ from baseline eGFR and/or an increase in basal serum creatinine $>0.2 \mathrm{mg} /$ $\mathrm{dL}$ was considered significant for renal damage; eGFR $<15$ $\mathrm{mL} / \mathrm{min} / 1.73 \mathrm{~m} 2$ was considered significant for chronic renal failure; patients with serum ALT and AST levels $>40 \mathrm{IU} / \mathrm{L}$ were considered significant for acute liver injury $(7,8)$; patients with serum troponin-I levels $>30 \mathrm{ng} / \mathrm{L}$ were considered significant for acute cardiac damage (9).

In our laboratory, reference ranges are determined by company recommendations; the normal reference range is indicated as ALT of 5-40 U/L, AST of 5-40 IU/L, troponin-I of 0-30 ng/L, urea of $15-44 \mathrm{mg} / \mathrm{dL}$, and creatinine of $0.6-1.4 \mathrm{mg} / \mathrm{dL}$. The eGFR value is calculated using the CKD-EPI system. Biochemical analyzes such as serum urea, creatinine, AST, ALT and troponin-I were measured at the Ministry of Health, Sultan 2. Abdülhamid Han Training and Research Hospital, Mustafa Gültepe Laboratory using in-house Gülhane Askeri Medical Academy kits applied to Abbott Architect C-16000 model autoanalyzer devices.

COVID-19 RT-PCR tests were analyzed in Sultan 2. Abdülhamid Han Training and Research Hospital authorized PCR laboratory with ROTORGEN brand device of QIAGEN using Bio-Speedy COVID-19 RT-qPCR detection kit recommended by Public Health Agency of Turkey (THSK).

\section{Study Limitations}

Since data on comorbid diseases are obtained from the anamnesis given by the person at the time of admission, some patients may have missed comorbid diseases. The reliability of the study could be increased by measuring myoglobin, creatinine kinase $\mathrm{MB}$ (CK-MB) level with serum troponin-I, and using methods such as myocardial perfusion scintigraphy and echocardiography in the evaluation of acute cardiac injury. The treatments used for comorbid diseases and whether the related diseases are under control could not be evaluated.

\section{Statistical Analysis}

Parametric tests were used without normality test due to the compatibility of the Central Limit Theorem (10). Student's t-test was used to compare the means of two independent groups, and the repeated ANOVA test was used to compare the means of more than two dependent groups. Chi-square test was used to evaluate the relationship between categorical variables. The exposure ratio (odds ratio) of variables thought to be associated with exitus status was given. Statistical significance level of the data was given as $\mathrm{p}<0.05$. www.e-picos.com New York software and MedCalc statistical package program were used to analyze the data.

\section{Results}

One hundred twenty of the patients (67\%) included in the study were male and their mean age was $60.9 \pm 16.4$ years. It was observed that at least one comorbid disease was detected in 104 patients, the most common comorbid diseases were HT and DM. At the time of admission, at least one acute organ injury was detected in 95 patients, with acute liver injury the most common. Fifty four of the study patients (30.2\%) died during the follow-up (Table 1).

When the relation of comorbid diseases, clinical findings and socio-demographic characteristics with mortality is evaluated statistically: the mean age of the patients who died was statistically significantly higher than the patients who were discharged with recovery; CHD, DM, and CRF were higher among comorbid diseases; acute cardiac damage at the time of admission and secondary bacterial infection development after hospitalization were higher $(p<0.05)$. No statistically significant difference was found between the two groups of patients for gender $(p>0.05)$ (Table 2).

When the factors affecting exitus and discharge with recovery are evaluated; DM (OR: 2.17, Cl: 1.1-4.3, p<0.05), COPD (OR: 2.18, Cl: 0.75-6.35, $\mathrm{p}<0.05$ ), asthma (OR: 3.01, Cl: 0.79-11.9, $\mathrm{p}<0.05$ ), CHD (OR: 2.4, Cl: 1.2-4.94, p<0.05), CRF (OR: 8.3, Cl: 3.01-22.8, $\mathrm{p}<0.05$ ), malignancy (OR: 1.6, Cl: 0.2-9.4, $\mathrm{p}<0.05$ ), acute cardiac damage (OR: 12.9, Cl: 5.5-30.5, $\mathrm{p}<0.05$ ), secondary bacterial infection development during follow-up (OR: 3.63, Cl: 1.5-8.6, $\mathrm{p}<0.05$ ) were statistically significant and it was found that they increased the mortality risk (Table 3 ).

\section{Discussion}

COVID-19 disease can be mild or cause death by causing severe respiratory failure. Since there is no specific treatment for the disease yet, pre-existing treatment agents are used in this disease. $\mathrm{HCQ}$, azithromycin and favipiravir combined triple therapy is recommended for COVID-19 patients with severe pneumonia and hypoxemia in our country. In our study, factors affecting mortality in patients meeting these criteria were examined.

In a study conducted by Guan et al. (11) with 1590 patients, the average age of the patients was 48.9; the mean age of the patient group with comorbidity was $60.8 ; 25 \%$ of all patients and $51.5 \%$ of patients with severe clinical picture had at least one comorbid disease; HT was the most common comorbid diseases with a rate of $16.9 \%$. Goyal et al. (12) stated in their study with 393 patients that the mean age of the patients was $62.2,35.8 \%$ of them were obese, HT was the highest comorbid disease with a rate of $50.1 \%$ and $10.2 \%$ of them died. In a study 
Table 1. Distribution of descriptive features of patients with COVID-19 $(n=179)$

\begin{tabular}{|c|c|c|}
\hline \multicolumn{2}{|l|}{ Descriptive Features } & \multirow{2}{*}{$\begin{array}{l}\mathrm{n}(\%) \\
\text { Min-max }\end{array}$} \\
\hline & $\overline{\mathbf{x}} \pm \mathrm{SD}$ & \\
\hline Age & $60.9 \pm 16.4$ & $21-96$ \\
\hline \multirow[t]{2}{*}{ Median (25\%-75\%) } & $62(50-73)$ & \\
\hline & & $n(\%)$ \\
\hline \multirow[t]{2}{*}{ Gender } & Male & $120(67)$ \\
\hline & Female & $59(33)$ \\
\hline \multirow[t]{2}{*}{ Mortalite } & Discharged & $125(69.8)$ \\
\hline & Ex & $54(30.2)$ \\
\hline \multirow[t]{2}{*}{ DM } & No & $127(70.9)$ \\
\hline & Yes & $52(29.1)$ \\
\hline \multirow[t]{2}{*}{ Hт } & No & $103(57.5)$ \\
\hline & Yes & 76 (42.4) \\
\hline \multirow[t]{2}{*}{ COPD } & No & $164(91.6)$ \\
\hline & Yes & $15(8.4)$ \\
\hline \multirow[t]{2}{*}{ Asthma } & No & $170(95)$ \\
\hline & Yes & $9(5)$ \\
\hline \multirow[t]{2}{*}{ CHD } & No & $137(76.5)$ \\
\hline & Yes & $42(23.5)$ \\
\hline \multirow[t]{2}{*}{ Malignancy } & No & $174(97.2)$ \\
\hline & Yes & $5(2.8)$ \\
\hline \multirow[t]{2}{*}{ Acute liver damage } & No & $113(63,1)$ \\
\hline & Yes & $66(36.9)$ \\
\hline \multirow[t]{2}{*}{ Acute cardiac damage } & No & $143(79.9)$ \\
\hline & Yes & $36(20.1)$ \\
\hline \multirow[t]{2}{*}{ Acute renal failure } & No & $153(85.5)$ \\
\hline & Yes & $26(14.5)$ \\
\hline \multirow[t]{2}{*}{ Chronic renal failure } & No & $157(87.7)$ \\
\hline & Yes & $22(12.3)$ \\
\hline \multirow[t]{2}{*}{ Secondary bacterial infection } & No & $154(86)$ \\
\hline & Yes & $25(14)$ \\
\hline
\end{tabular}

DM: Type 2 diabetes mellitus, HT: Essential hypertension, COPD: Chronic obstructive pulmonary disease, CHD: Chronic heart disease, SD: Standard deviation, min: Minumum, max: Maximum conducted by Cao et al. (13) with 198 patients, the average age of all patients was 50.1 , and $34 \%$ of the patients had at least one comorbid disease. It was observed that the rate of at least one comorbid disease in patients hospitalized in the ICU was $52 \%$. While the most common comorbid disease in patients was HT with a rate of $21 \%$, HT $(31 \%)$ and CHD (26\%) were the most common in patients admitted to the ICU. In a study conducted by Richardson et al. (14) with 5700 patients, the mean age of the patients was 63 years, and the most common accompanying disease was found to be HT (56.6\%). In this study, it was stated that $41.7 \%$ of the patients were obese and $19 \%$ were morbidly obese. In our study, while the mean age of our patients was higher than the studies of Guan et al. (11) and Cao et al. (13), it was lower than that of Goyal et al. (12) and Richardson et al. (14). Similar to the studies of these four researchers, we observed that the most common comorbid disease in our study patients was HT. Goyal et al.(12) and Richardson et al. (14) stated that both high average age of the study patients and higher rates of obesity could explain the more frequent occurrence of HT. Because our study patients are of advanced age and have a severe clinical picture, we concluded that we reached HT rates similar to the studies conducted by Goyal et al. (12) and Richardson et al. (14) Ignoring the exclusion criteria, we also concluded that if the COVID-19 RT-PCR positive 683 patients were analyzed, our average patient age and HT rate could be lower.

In a study conducted with 198 patients, Cao et al. (13) stated that the distribution of men and women was equal, $90 \%$ of the 19 patients admitted to the ICU were men, and accordingly, the male gender had risk factors associated with the severity of the COVID-19 disease. Jian et al. (15), in a study conducted with 43 patients, stated that the rate of getting the disease was equal in women and men, while they observed that the disease was mortal in $70.3 \%$ of male patients and $29.7 \%$ of female patients. In addition, it has been stated that the number of men who die is 2.4 times more than women, and that COVID-19 disease causes more mortality in male patients regardless of age. Richardson et al. (14) stated that $60.3 \%$ of the patients were male, but gender had no effect on mortality in their study. In our study, we concluded that although the male sex ratio was higher in the whole patient population and the exitus group, gender did not make a statistically significant difference on the severity and mortality of the disease.

Guan et al. (11) stated in their study that COPD, DM, HT and malignancy comorbid diseases led to a 2.68, 1.59, 1.58 and 3.5 -fold increase in mortality risk, respectively. In our study, COPD increased the risk of mortality by 2.18 , DM 2.17 , and malignancy 1.6 times. Our findings were similar to those found by Guan et al. (11) for these three comorbid diseases. Even though it was observed in our study that HT caused an increase in mortality risk 1.7 times, we found that it was not statistically significant. We surmised that the use of antihypertensive therapy and controlling arterial blood pressure in patients with HT may have limited the effect of hypertension on mortality. It is clear that studies to be conducted by evaluating antihypertensive treatment options and treatment compliance rates of patients in large patient groups are needed. 
Table 2. Statistical relations between socio-demographic characteristics, acute organ damage and secondary bacterial infections during follow-up and discharge with exitus/recovery status ( $n=179)$

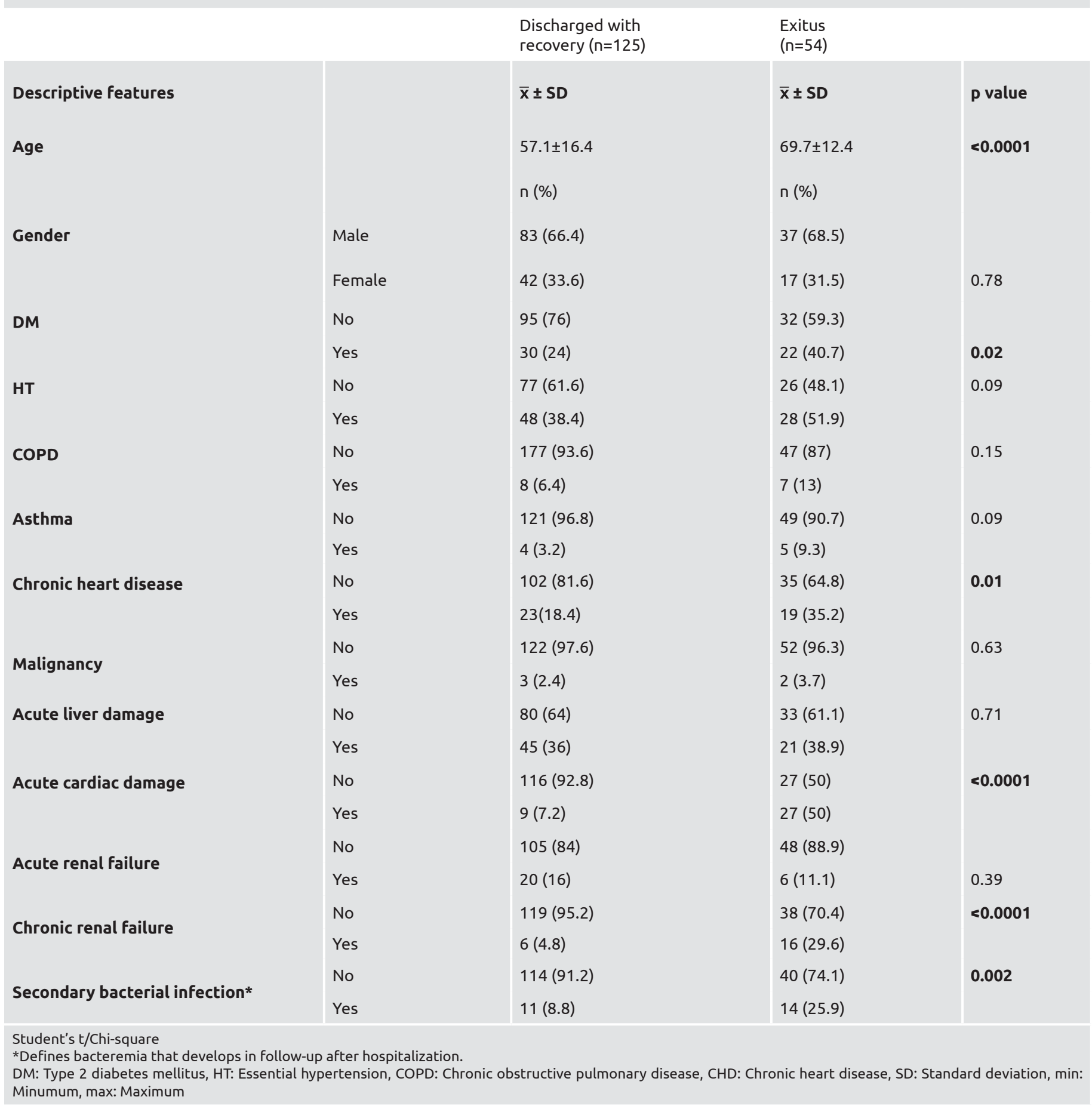

Rowson et al. (16) reported that $8 \%$ of 806 COVID-19 patients had bacterial/fungal co-infections during admission to the hospital. Goyal et al. (12) stated that 130 of 393 patients followed up in ICU received invasive mechanical ventilation support, $5.6 \%$ of patients developed bacteremia during followup and $10.2 \%$ of the patients resulted in death. No data are given on agents that cause bacteremia. $43 \%$ of our study patients were followed up in the ICU and bacteremia developed in 14\% of these patients during the follow-up, and Klebsiella pneumoniae and Acinetobacter baumanii were the most common bacteremia agents. The patients who developed bacteremia were: those who were followed for more than 7 days under invasive mechanical ventilation support; those with cytokine release syndrome, those with multiple organ failure and shock; and those with underlying comorbid diseases. It was thought that the reason for our secondary bacterial infection rate to be higher than other studies 


\begin{tabular}{|c|c|c|c|c|}
\hline Variable & $\begin{array}{l}\text { Odds } \\
\text { ratio }\end{array}$ & $\begin{array}{l}\text { Lower } \\
(95 \% \mathrm{Cl})\end{array}$ & $\begin{array}{l}\text { Upper } \\
(95 \% \mathrm{Cl})\end{array}$ & $\mathrm{p}$ value \\
\hline DM & 2.17 & 1.1 & 4.3 & $\begin{array}{l}\text { Significant } \\
(p<0.05)\end{array}$ \\
\hline HT & 1.7 & 0.91 & 3.29 & $\begin{array}{l}\text { Insignificant } \\
(p>0.05)\end{array}$ \\
\hline COPD & 2.18 & 0.75 & 6.35 & $\begin{array}{l}\text { Significant } \\
(p<0.05)\end{array}$ \\
\hline Asthma & 3.01 & 0.79 & 11.9 & $\begin{array}{l}\text { Significant } \\
(p<0.05)\end{array}$ \\
\hline CHD & 2.4 & 1.2 & 4.94 & $\begin{array}{l}\text { Significant } \\
(p<0.05)\end{array}$ \\
\hline Malignancy & 1.6 & 0.2 & 9.4 & $\begin{array}{l}\text { Significant } \\
(p<0.05)\end{array}$ \\
\hline $\begin{array}{l}\text { Acute liver } \\
\text { damage }\end{array}$ & 1.13 & 0.59 & 2.18 & $\begin{array}{l}\text { Insignificant } \\
(p>0.05)\end{array}$ \\
\hline $\begin{array}{l}\text { Acute cardiac } \\
\text { damage }\end{array}$ & 12.9 & 5.5 & 30.5 & $\begin{array}{l}\text { Significant } \\
(p<0.05)\end{array}$ \\
\hline $\begin{array}{l}\text { Acute renal } \\
\text { failure }\end{array}$ & 0.65 & 0.25 & 1.74 & $\begin{array}{l}\text { Insignificant } \\
(p>0.05)\end{array}$ \\
\hline CRF & 8.3 & 3.01 & 22.8 & $\begin{array}{l}\text { Significant } \\
(p<0.05)\end{array}$ \\
\hline $\begin{array}{l}\text { Secondary } \\
\text { bacterial } \\
\text { infection** }\end{array}$ & 3.63 & 1.5 & 8.6 & $\begin{array}{l}\text { Significant } \\
(p<0.05)\end{array}$ \\
\hline \multicolumn{5}{|c|}{$\begin{array}{l}\text { * Significant at } p<0.05 \text { level (Odds ratio). } \\
\text { **Defines bacteremia that develops in follow-up after hospitalization. } \\
\text { DM: Type } 2 \text { diabetes mellitus, HT: Essential hypertension, COPD: Chronic } \\
\text { obstructive pulmonary disease, CHD: Chronic heart disease, Cl: Confidence } \\
\text { interval, CRF: Chronic renal failure }\end{array}$} \\
\hline
\end{tabular}

was that our patients were hypoxaemic, severe pneumonia cases and could be associated with prolonged hospitalization.

In the study by Cao et al. (13), while it was reported that $17 \%$ of all patients had acute liver damage, $5 \%$ had acute renal failure, $11 \%$ had acute cardiac toxicity, $42 \%$ of the patients followed in the ICU have acute liver damage, $15 \%$ have acute renal failure, and $47 \%$ have acute cardiac toxicity. In our study patients, we found lower rates of acute liver injury and acute cardiac toxicity, and similar rates of acute renal failure. In our study, it was determined that $50 \%$ of the patients who died had acute cardiac damage and its relation with mortality was statistically significant.

$\mathrm{Du}$ et al. (17) reported that 21 of 179 patients diagnosed with COVID-19 who were hospitalized were lost; they stated that being over 65 years old, having a history of cardiovascular and cerebrovascular disease, having CD3 + CD8 + T lymphocyte count $\leq 75$ cells $/ \mu \mathrm{L}$ and serum troponin-I level of $\geq 0.05 \mathrm{ng} / \mathrm{mL}$ were associated with mortality. They stated that low CD3 + CD8 + T lymphocyte count and high troponin-I level were predictors for mortality of COVID-19 pneumonia patients. Our mortality rates were higher in our study compared to other studies. We think that our mortality rate was higher due to the fact that our study patients showed severe pneumonia symptoms and were followed for a long time in the ICU with invasive mechanical ventilation support. In our study, serum troponin-I elevation was found 12.9 times higher in the patient group who died, and it was evaluated as a predictor for mortality in COVID-19 pneumonia patients.

Although the number of our patients who received tocilizumab and convalescent immune plasma treatment was small, when the effects of these treatments on mortality were evaluated, 6 of 19 (31.5\%) patients who received tocilizumab treatment and 7 of $13(53.8 \%)$ patients who received convalescent immune plasma died. While the mortality rate in the group receiving tocilizumab treatment was similar to our general patient population, the mortality rate was higher in patients who received convalescent immune plasma therapy. When 13 patients who were treated with convalescent immune plasma were retrospectively analyzed, it was observed that the positivity continued for a longer time in recurrent nasopharyngeal/oropharyngeal swab COVID-19 PCR samples. Although it was concluded that long-term nasopharyngeal/oropharyngeal virus load might increase the mortality of patients, it was thought that studies with more patients are needed.

\section{Conclusion}

In COVID-19 patients with pneumonia and hypoxemia, where favipiravir-based drug treatment options are used effectively in accordance with current guideline recommendations; advanced age, DM, CHD, CRF, increased serum troponin-I at the time of first admission and secondary bacterial infection development at follow-up were determined as mortality-related factors. CRF and acute cardiac injury have been evaluated to be predictors of mortality in patients with severe pneumonia diagnosed with COVID-19.

\section{Ethics}

Ethics Committee Approval:This study was approved by the University Health of Science, Hamidiye Scientific Research Ethics Committee (decision number 20/182 dated 15.05.2020).

Peer-review: Externally peer reviewed.

\section{Authorship Contributions}

Surgical and Medical Practices: B.S., Concept: B.S., S.Ç.E., Design: B.S., S.Ç.E., Data Collection or Processing: B.S., Analysis or Interpretation: B.S., S.Ç.E., Literature Search: B.S., S.Ç.E., Writing: B.S.

Conflict of Interest: No conflict of interest was declared by the authors.

Financial Disclosure: The authors declared that this study received no financial support.

\section{References}

1. Richman DD, Whitley RJ, Hayden FG. Clinical virology. 4th ed. Washington: ASM Press; 2016:273-91. 
2. TG Ksiazek, D Erdman, CS Goldsmith, Zaki RS, Teresa P, Emery $S$, et al. A novel coronavirus associated with severe acute respiratory syndrome. N Engl J Med 2003;348:1953-66.

3. WHO. Novel coronavirus - China. Jan 12, 2020. Last Accessed Date: 19.01.2020. Avaialeble from: http://www.who.int/csr/don/12january-2020-novel-coronavirus-china/en/

4. WHO. Coronavirus disease (COVID-19) pandemic. Last Accessed Date: 07.07.2020. Available from: https://www.who.int/emergencies/ diseases/novel-coronavirus-2019.

5. McCreary EK, Pouge JM. Coronavirus disease 2019 treatment: a review of early and emerging options. Open Forum Infect Dis 2020;7:ofaa105.

6. Simsek Yavuz S, Unal S. Antiviral treatment of COVID-19. Turk J Med Sci. 2020;50:611-9.

7. Wang X, Fang X, Cai Z, Wu X, Gao X, Min J, et al. Comorbid chronic diseases and acute organ injuries are strongly correlated with disease severity and mortality among COVID-19 patients: a systemic review and meta-analysis. Research Wash DC 2020:2402961

8. Chai XQ, Hu LF, Zhang Y, Han W, Lu Z, Ke A, et al. Specific ACE2 Expression in Cholangiocytes May Cause Liver Damage After 2019nCoV Infection. Preprint. Posted online February 03, 2020. bioRxiv 931766. doi: 10.1101/2020.02.03.931766

9. Hui H, Zhang Y, Yang X, Wang X, He B, Li L, et al. Clinical and radiographic features of cardiac injury in patients with 2019 novel coronavirus pneumonia, medRxiv preprint (2020), 10.1101/2020.02.24.20027052

10. Norman G. Likert scales, levels of measurement and the "laws" of statistics. Adv in Health Sci Educ Theory Pract 2010;15:625-32.
11. Guan WJ, Liang WH, Zhao Y, Liang HR, Chen ZS, Li YM, et al. Comorbidity and its impact on 1590 patients with Covid-19 in China: a nationwide analysis [published online ahead of print March 26, 2020]. Eur Respir J 2020;55:2000547 https://doi. org/10.1183/13993003.00547-2020.

12. Goyal P, Choi JJ, Pinheiro LC, Schenck EJ, Chen R, Jabri A, et al. Clinical characteristics of Covid-19 in New York City. N Engl J Med 2020;382:2372-4. Published online April 17, 2020. doi:10.1056/ NEJMc2010419

13. Cao M, Zhang D, Wang Y, Lu Y, Zhu X, Li Y, et al. Clinical features of patients infected with the 2019 novel coronavirus (COVID-19) in Shanghai, China. medRxiv. Epub ahead of print 4 March 2020. DOI: $10.1101 / 2020.03 .04 .20030395$

14. Richardson S, Hirsch JS, Narasimhan M, Crawford JM, McGinn T, Davidson KW, et al. Presenting characteristics, comorbidities, and outcomes among 5700 patients hospitalized with COVID-19 in the New York City area. JAMA 2020;323:2052-9. Published online April 22, 2020. doi:10.1001/jama.2020.6775

15. Jin J, Bai P, He W, Wu F, Liu WF, Han DM, et al. Yang Gender differences in patients with COVID-19: focus on severity and mortality Front Public Health 2020;8:152.

16. Rawson TM, Moore LSP, Zhu N, Ranganathan N, Skolimowska K, Gilchrist $\mathrm{M}$, et al. Bacterial and fungal co-infection in individuals with coronavirus: A rapid review to support COVID-19 antimicrobial prescribing. Clin Infect Dis 2020;2:ciaa530. doi: 10.1093/cid/ ciaa530. Online ahead of print.

17. Du RH, Liang LR, Yang CQ, Wang W, Cao TZ, Li M, et al. Predictors of mortality for patients with COVID-19 pneumonia caused by SARS-CoV-2: a prospective cohort study Eur Respir J 2020;55:2000524. 